\title{
Indium In 111 Bevacizumab
}

National Cancer Institute

\section{Source}

National Cancer Institute. Indium In 111 Bevacizumab. NCI Thesaurus. Code C74046.

A radioimmunoconjug ate comprised of the recombinant humanized monoclonal antibody bevacizumab conjug ated with the gamma-emitting radioisotope indium In 111 . Indium I 111 bevacizumab binds to vascular endothelial growth factor (VEGF), allowing the detection of VEGF distribution using gamma scintigraphy. 